\title{
The impact of habitat disturbance by scallop dredging on marine benthic communities: what can be predicted from the results of experiments?
}

\author{
Simon F. Thrush ${ }^{1, *}$, Judi E. Hewitt ${ }^{1}$, Vonda J. Cummings ${ }^{1}$, Paul K. Dayton ${ }^{2}$ \\ ${ }^{1}$ National Institute of Water and Atmospheric Research, PO Box 11-115, Hamilton, New Zealand \\ ${ }^{2}$ Scripps Institution of Oceanography, University of California San Diego, La Jolla, California 92093-0201, USA
}

\begin{abstract}
Field experiments were conducted on 2 subtidal sandflats to identify the short-term impacts of commercial scallop dredging on macrobenthic communities. The 2 sites $\left(1400 \mathrm{~m}^{2}\right)$ were situated $14 \mathrm{~km}$ apart, both at about $24 \mathrm{~m}$ depth, with similar exposure aspects and were characterised by infaunal communities dominated by small and short-lived species. Prior to dredging, preliminary sampling failed to reveal significant differences in the density of common macrofauna within each site, although community composition was distinctly different between sites. The experiment was initiated by using a commercial scallop dredge to dredge half of each study site. Macrofauna samples were collected in both the dredged and adjacent reference plot at each site immediately after dredging and again 3 mo later. The density of common macrofaunal populatıons at each site decreased as a result of dredging, with some populations still significantly different from the adjacent reference plot after 3 mo. Significant compositional differences in the assemblage structure between dredged and reference plots were also recorded at each site over the course of the experiment. The findings of this experiment are considered a conservative assessment of bottom disturbance by fishing because of the area of seabed used, the types of community present and the intensity of disturbance used in the experiment. The findings of this and similar short-term experiments are discussed in light of the need to predict and assess possible large-scale changes to benthic communities as a result of habitat disturbance by fishing.
\end{abstract}

KEY WORDS: Fishing impacts - Habitat disturbance - Scallop dredging - Benthic communities Scaling-up

\section{INTRODUCTION}

With the increasing utilisation of fishery resources around the world there is growing concern about the potential for extensive impacts on marine ecosystems. The ecological consequences of a variety of other human activities that modify coastal ecosystems (e.g. urbanisation, reclamation and pollution), although often intense, usually occur on a far more localised scale than the extensive area exploited by commercial fishers. In fact, the spatial and temporal extent of commercial fishing activity has been a major factor limiting our ability to identify interactions between fishing activity and the broad-scale structure and functioning

•E-mail: thrush@eco.cri.nz of marine ecosystems. This is unfortunate because the issue of the environmental effects of fishing is important, not solely for conservation, but also because exploited species are integral components of natural systems; any broader effects of their exploitation are likely to have important ramifications for the fishing industry, its management and sustainability.

A number of recent studies have highlighted the variety of effects that can occur as a result of fishing (de Groot 1984, Aronson 1990, Messieh et al. 1991, Jones 1992, Whitman \& Sebens 1992, Dayton et al. in press). A potentially important mechanism whereby fishing may influence benthic communities is habitat disturbance by bottom dredging and trawling. Without direct measurements of the spatial distribution and frequency of fishing disturbance, the appropriate scales from which to assess the potential impact have been 
difficult to resolve. However, some studies indicate the potential for long-term ecosystem-wide changes due to bottom disturbance by fishing (e.g. Wadden Sea, Riesen \& Reise 1982; English Channel, Holme 1983; Australian North West Shelf, Sainsbury 1988). These studies indicate the need to consider impacts over a variety of spatial and temporal scales, ranging from the immediate effects of short-term differences in and out of individual trawl or dredge tracks, to long-term changes in the structure and functioning of benthic communities in fishing grounds.

In most cases a rigorous assessment of the effects of habitat disturbance by fishing is not possible. The lack of pre-fishing data precludes the use of BACI impact assessment procedures (Green 1979, StewartOaten et al. 1986, Underwood 1992). The large space and time scales over which fishing operates further complicate the situation, making it difficult to identify areas which have not already been modified by previous exploitation and to locate comparable control/ impact sites. However, small-scale experiments that focus on effects at the scale of an individual trawl or dredge track are possible; here we present the results of an experiment designed to identify short-term (up to $3 \mathrm{mo}$ ) effects of scallop dredging on macrobenthic communities. The problems involved in utilising information gained from small-scale experiments such as this, to predict and test for effects over larger scale, are also discussed.

\section{METHODS}

Experiments were conducted in the Mercury Bay area $\left(36^{\circ} 45^{\prime} \mathrm{S}, 175^{\circ} 50^{\prime} \mathrm{W}\right)$ of the Coromandel Peninsula, New Zealand. Two locations were selected for the experiment, these were chosen on the basis of local knowledge of scallop dredging activity, and for similarities in water depth and exposure aspect. The 2 locations selected were about $14 \mathrm{~km}$ apart, one in an area regularly exploited by commercial scallop fishers (Opito Bay) and the other in an unexploited area (Hahei).

Based on preliminary diving observations at each location, a representative site $(70 \times 20 \mathrm{~m})$ was chosen. Sub-surface marker buoys were used to permanently mark the corners of each site and a series of metal stakes were placed down the middle of the site. On each sampling occasion, a transect line marked at $1 \mathrm{~m}$ intervals was run along the metal stakes and used to find sampling locations determined by random selection of cartesian coordinates for each side of the transect line.

Prior to the actual experiment, 15 randomly positioned cores $(10 \mathrm{~cm}$ diameter, $15 \mathrm{~cm}$ depth) were col- lected by SCUBA diving to describe the macrobenthic community and determine any spatial variation within each site. Observations of habitat type and the densities of large epifauna were also made while SCUBA diving. Surface sediment samples (0 to $5 \mathrm{~cm}$ depth) were collected haphazardly from each site. For each site, these samples were pooled prior to grain size analysis following the methods described in Folk (1968).

The experiment was initiated in late April 1991, 3 wk after preliminary sampling, by running a commercial scallop dredge through half of each study site. The commercial fishing vessel used a box dredge (about $2.4 \mathrm{~m}$ wide) typical of those used by local scallop fishers. This type of dredge is only used in New Zealand and Australia and is similar to that described by McLoughlin et al. (1991). Although the penetration depth of the dredge into the seabed is influenced by a variety of factors, under the conditions used in this experiment we expected the dredge to drag across the sediment. A tooth bar, with teeth about $10 \mathrm{~cm}$ long, fitted to the lower leading edge of the dredge, scored the sediment surface. Surface buoys were positioned over the central transect line and 5 parallel dredge tows were made along the long axis of each site, to create a dredged plot and an adjacent reference plot. At both sites core samples were collected by SCUBA diving, within $2 \mathrm{~h}$ of dredging and again 3 mo later. On both of these sampling occasions 12 core samples were collected from random locations in each of the dredged and reference plots. Observations of sediment conditions and epifauna were also made.

Macrofaunal core samples were sieved on a $500 \mu \mathrm{m}$ mesh. The residue from each sample was fixed in $5 \%$ formalin and $0.1 \%$ Rose Bengal in seawater. In the laboratory macrofauna were sorted, identified to the lowest practical taxonomic level, counted and preserved in $70 \%$ isopropanol.

Tests of significant differences between plots and times were conducted on the densities of common taxa (i.e. taxa represented by an average of greater than 2 individuals per core). The significance of differences between dredged and reference plots, between occasions, and their interactive effects were assessed using 2-way ANOVA, with both factors treated as fixed effects. Data from Hahei and Opito Bay were treated separately because the macrobenthic communities at each site were distinctly different. Data were initially analysed to assess normality (Shapiro-Wilk test) and homogeneity of variance (Levene's test). For taxa which could not meet these assumptions, the data were rank transformed prior to ANOVA (Conover \& Iman 1981). Statistical significance was attributed to univariate tests at the $10 \%$ 
level. While this a priori decision allows for greater probability of falsely concluding that a significant effect exists (i.e. making a Type I error) than the traditional level of $5 \%$, it is important that due regard also be paid to Type II error (i.e. falsely concluding that no effect exists when there really is one). Type II error is at least as important as Type I error when documenting impacts on the environment and when providing information with implications for resource management (see Eberhardt \& Thomas 1991, Fairweather 1991, Peterman \& M'Gonigle 1992, Peterson 1993 for further discussion).

The compositional differences between the macrobenthic assemblages found in the dredged and reference plots and through time were assessed using the Bray-Curtis similarity index (Bray \& Curtis 1957) followed by multi-dimensional scaling (MDS) ordination (Kruskal \& Wish 1978). This technique is frequently used to assess changes in community structure associated with environmental impact (Clarke 1993, Warwick 1993). In all cases MDS ordinations presented are based on untransformed data and had stress levels $<0.15$. Differences in assemblage composition between plots and times were assessed using ANOSIM, a randomization/permutation procedure that tests for differences in the ranked similarity matrix, both in terms of location and variability (Clarke \& Green 1988).

\section{RESULTS}

\section{Preliminary sampling}

Mean sediment grain size at both sites was characterised as coarse sand (Table 1). Sediments at Hahei were well sorted with a slightly coarse skewed distribution. Observations of the sediment surface at Hahei indicated sediments were homogeneous over the site and composed of small sand ripples $(<10 \mathrm{~cm}$ high). The sediment surface at the Opito Bay site consisted of an unrippled sandflat with a large fraction of shell hash. This resulted in sediments being characterised as poorly sorted and strongly coarse skewed (Table 1). Common epibenthic animals at both sites were all mobile and included starfish Astropecten

Table 1. Near-surface sediment grain size statistics

\begin{tabular}{|lcccc|}
\hline Site & $\begin{array}{c}\text { Mean size } \\
(\phi)\end{array}$ & $\begin{array}{c}\text { Mean size } \\
(\mathrm{mm})\end{array}$ & Sorting & Skewness \\
\hline Hahei & 2.590 & 0.166 & 0.501 & -0.102 \\
Opito Bay & 2.150 & 0.225 & 1.099 & -0.406 \\
\hline
\end{tabular}

polyacanthus and Luidia varia, hermit crabs Paguristes setosus and snails Cominella adspersa. Scallops Pecten novaezelandiae were only abundant at the Opito Bay site.

Tests on all common taxa, the total number of individuals and number of taxa from the macrofaunal samples collected prior to experimental dredging failed to identify any significant pre-experiment location differences within either of the sites (Table 2) The community composition was distinctly different between the 2 sites, with crustaceans more common at Hahei and polychaetes more common at Opito Bay (Table 3). The MDS ordination (Fig. 1) also demonstrated distinct differences between the 2 sites, with samples from Opito Bay showing higher variability in assemblage composition than those from Hahei. ANOSIM assessment of differences in the ranked similarity matrix revealed an overall significant difference between the 2 sites ( $p=0.002$ ).

Table 2. Tests for location affects prior to dredging. Data collected from each half of the site were compared using Wilcoxon's rank sum tests $(n=7)$

\begin{tabular}{|c|c|}
\hline Taxa & Probability \\
\hline \multicolumn{2}{|l|}{ Hahei } \\
\hline \multicolumn{2}{|l|}{ Crustaceans } \\
\hline Ostracods & $<0.325$ \\
\hline Phoxocephalid complex & $<0.772$ \\
\hline Tanaidae 1 & $<0.684$ \\
\hline Gynodiastylis laevis & $<0.609$ \\
\hline Urothoe spp. & $<0.561$ \\
\hline Pachychelium sp. & $<0.639$ \\
\hline \multicolumn{2}{|l|}{ Polychaetes } \\
\hline Euchone sp. & $<0.602$ \\
\hline Aricidea sp. & $<0.811$ \\
\hline \multicolumn{2}{|l|}{ Molluscs } \\
\hline Felaniella zelandica & $<0.859$ \\
\hline Total no. of individuals & $<0.862$ \\
\hline Total no. of taxa & $<0.813$ \\
\hline \multicolumn{2}{|l|}{ Opito Bay } \\
\hline \multicolumn{2}{|l|}{ Crustaceans } \\
\hline Ostracods & $<0.746$ \\
\hline Phoxocephalid complex & $<0.688$ \\
\hline Gynodiastylis laevis & $<0.320$ \\
\hline \multicolumn{2}{|l|}{ Polychaetes } \\
\hline Polydora sp. & $<0.477$ \\
\hline Goniadides sp. & $<0.865$ \\
\hline Euchonesp. & $<0.954$ \\
\hline Prionospio multicristata & $<0.277$ \\
\hline Macroclymenella stewartensis & $<0.305$ \\
\hline \multicolumn{2}{|l|}{ Molluscs } \\
\hline Tawera spissa & $<0.836$ \\
\hline Total no. of individuals & $<0.518$ \\
\hline Total no. of taxa & $<0.313$ \\
\hline
\end{tabular}


Table 3. Initial composition of dominant macrofauna at Hahei and Opito Bay. C: crustacean; $P$ : polychaete; $M$ : mollusc

\begin{tabular}{|lc|}
\hline Taxa & \% of individuals \\
\hline Hahei & \\
C Ostracods & 18.0 \\
P Euchone sp. & 17.7 \\
C Phoxocephalid complex & 12.8 \\
C Tanaidae 1 & 12.0 \\
C Gynodiastylis laevis & 6.2 \\
C Urothoe spp. & 5.2 \\
M Felaniella zelandica & 3.4 \\
C Pachychelium sp. & 3.2 \\
P Aricidae sp. & 2.1 \\
& \\
Opito Bay & \\
P Polydora sp. & 57.9 \\
C Ostracods & 7.1 \\
C Phoxocephalid complex & 4.3 \\
P Goniadides sp. & 4.2 \\
P Euchone sp. & 3.3 \\
P Prionospio multicristata & 2.5 \\
P Gynodiastylis laevis & 2.2 \\
M Tawera spissa & 2.2 \\
P Macroclymenella stewartensis & 2.1 \\
\hline
\end{tabular}

\section{Visible effects of dredging}

The impacts to the seafloor observed by SCUBA diving immediately after dredging were similar at both sites. The dredge broke down the natural surface features (e.g. emergent tubes, sediment ripples) and the teeth on the front of the dredge created grooves approximately 2 to $3 \mathrm{~cm}$ deep. These observations indicated that the dredge had disturbed the dredged plot but not the adjacent reference plot. At both sites, dredge tracks occasionally did not completely overlap, indicating the presence of small undredged

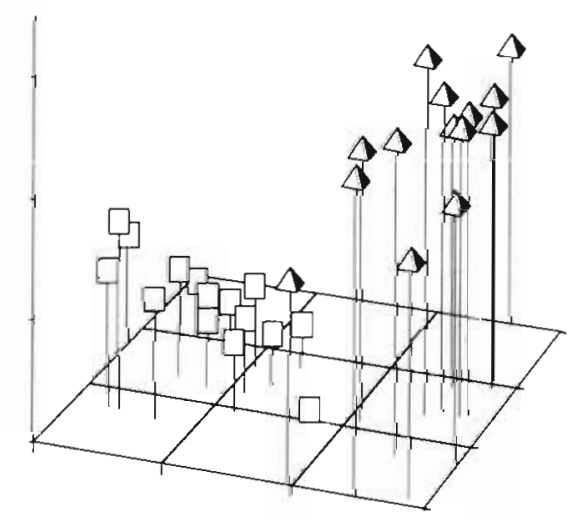

Fig. 1. MDS ordination of data from core samples collected on the preliminary sampling occasions. The ordination recorded a stress level of 0.073. ( $\square$ ) Hahei; ( $\Delta$ ) Opito Bay patches which could increase the variability of samples from the dredged plots. This did not influence data collected immediately after dredging, when dredge tracks were visible. At both sites undamaged scavenging snails, hermit crabs and starfish were highly active, feeding on damaged and exposed macrofauna. In Opito Bay many damaged scallops were lying on the sediment surface, already being attacked by scavengers.

\section{Effects on macrofauna at Hahei}

Of the common taxa at Hahei, the crustaceans of the Phoxocephalid complex, Tanaidae 1, and Urothoe spp., and the polychaetes Aricidea sp., Onuphis aucklandensis, and Prionospio multicristata, all showed consistent significant differences between the dredged and reference plot, while the crustacean Pachychelium sp. and the bivalve Nucula nitidula showed significant differences on at least one sampling occasion (Fig. 2, Table 4). For all of these taxa densities were lower in the dredged plot on the first sampling occasion. Three species (the crustacean Leucon ?latispina, the polychaete Euchone sp., and the bivalve Felaniella

Table 4. Significance of 2-way ANOVA on common taxa, total number of individuals and number of taxa from the Hahei experimental site core samples. Degrees of freedom are as follows: Plot 1; Time 1; Interaction 1; Error 44. Probability values above 0.1 are presented as non-significant (ns)

\begin{tabular}{|c|c|c|c|}
\hline Taxa & Plot & Time & Interaction \\
\hline \multicolumn{4}{|l|}{ Crustaceans } \\
\hline Gynodiastylis laevis & ns & ns & ns \\
\hline Leucon?latispina & ns & 0.0001 & ns \\
\hline Ostracods & ns & ns & ns \\
\hline Pachychelium sp. & ns & ns & 0.0909 \\
\hline $\begin{array}{l}\text { Phoxocephalid } \\
\text { complex. }\end{array}$ & 0.0551 & ns & 0.0312 \\
\hline Tanaidae $1^{*}$ & 0.0001 & ns & ns \\
\hline Urothoe spp. & 0.0551 & ns & ns \\
\hline \multicolumn{4}{|l|}{ Molluscs } \\
\hline Felaniella zelandica & ns & 0.0233 & ns \\
\hline Nucula nitidula. & ns & ns & 0.0113 \\
\hline \multicolumn{4}{|l|}{ Polychaetes } \\
\hline Ancidea sp." & 0.0191 & ns & 0.0964 \\
\hline Euchonesp. & ns & 0.0052 & ns \\
\hline $\begin{array}{l}\text { Onuphis } \\
\text { aucklandensis. }\end{array}$ & 0.0622 & ns & ns \\
\hline $\begin{array}{l}\text { Prionospio } \\
\text { multicristata }\end{array}$ & 0.0543 & ns & ns \\
\hline Total no. of individuals & 0.0142 & ns & ns \\
\hline Total no. of taxa & ns & $\mathrm{ns}$ & 0.0173 \\
\hline - ANOVA based on ranks & & & \\
\hline
\end{tabular}



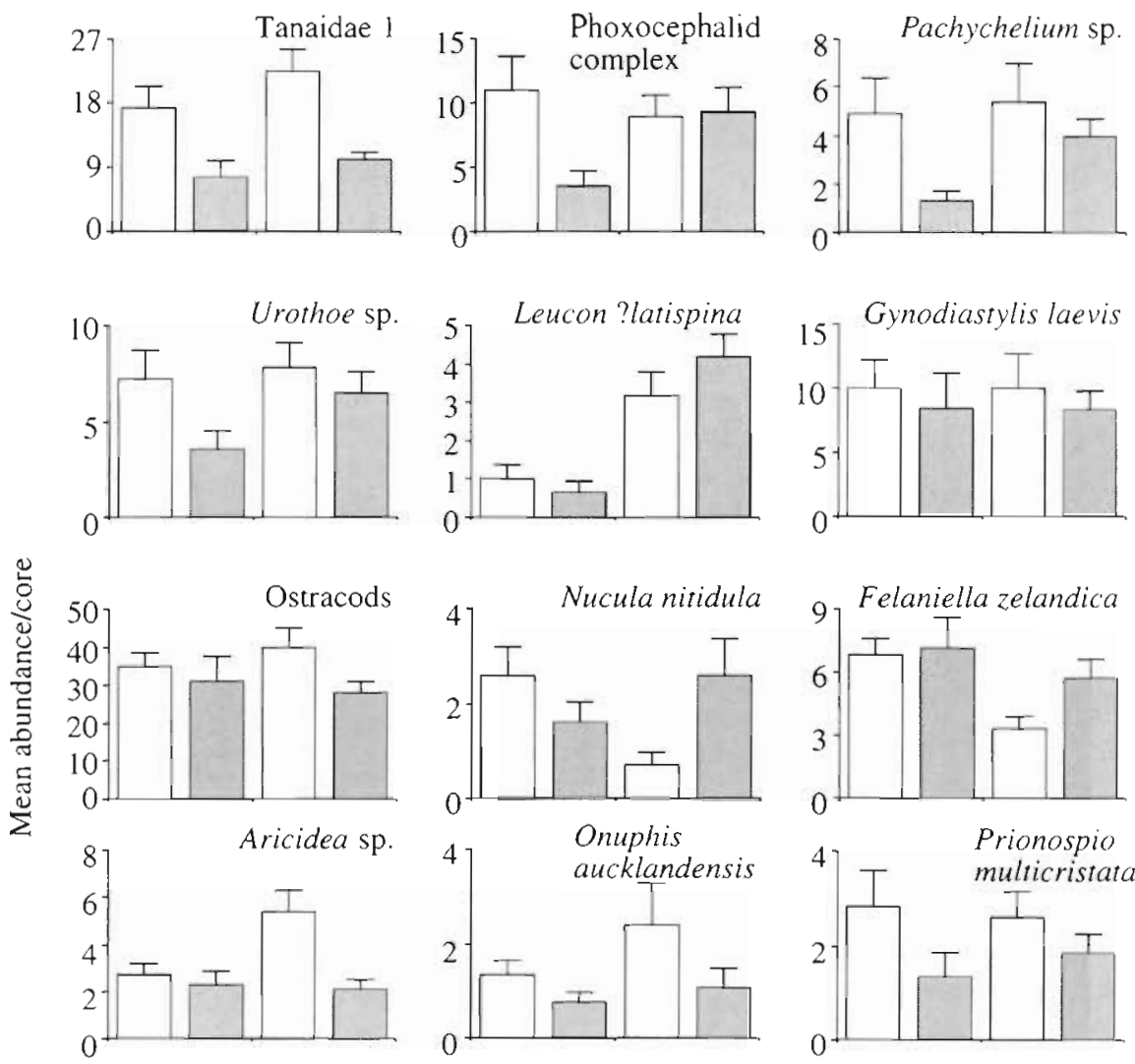

Fig. 2. Mean density ( \pm SE) of common taxa, total number of individuals, number of taxa collected in core samples from dredged (shaded) and reference (unshaded) plots at Hahei
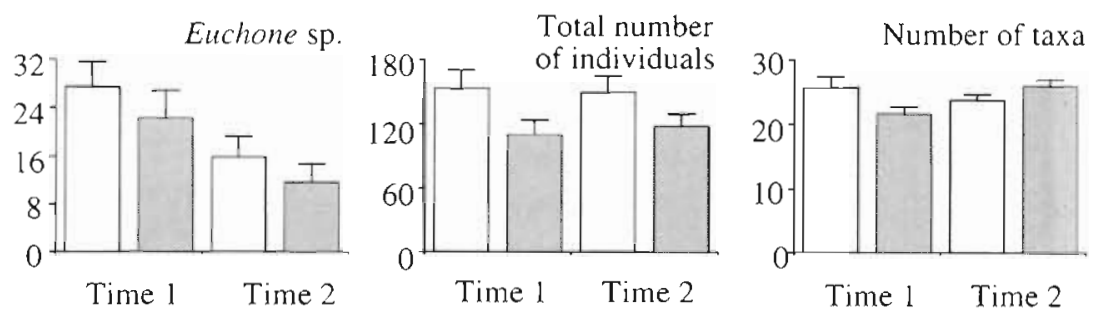

zelandica) showed significant density changes over time. These taxa did not show a significant effect due to dredging. The remaining common taxa were usually those with low and/or variable densities, i.e. the crustaceans Gynodiastylis laevis and Ostracods. Although they did not show significant differences, a general pattern of lower mean densities in the dredged plot in comparison to the reference plot is apparent on the first sampling occasion (Fig. 2).

The total number of individuals was significantly lower in the dredged plot on both sampling accasions (Fig. 2, Table 4). The number of taxa was lower in the dredged plot only on the first sampling occasion, accounting for the significant plot $x$ time interaction (Table 4). The MDS ordination from Hahei demonstrated differences in both location and spread of core samples collected in dredged and reference plots over time (Fig. 3). ANOSIM assessment of differences in the ranked similarity matrix demonstrated an overall dif- ference between factors ( $p=0.002$ ) due to differences between dredged and reference plots on each sampling occasion ( $p<0.05$ respectively). Macrobenthic samples collected on the preliminary sampling occasion and from the reference plot on the other 2 sampling occasions were not significantly different from each other.

\section{Effects on macrofauna at Opito Bay}

Temporal changes in the density of resident species appeared to be common at the Opito Bay site over the 3 mo of the experiment. Five taxa (i.e. the crustaceans Gammaridae and Ostracods, the polychaetes Euchone sp. and Macroclymenella stewartensis, and the bivalve Felaniella zelandical showed significant density changes with time (Table 5). Patterns of density change between the dredged and reference plot were 


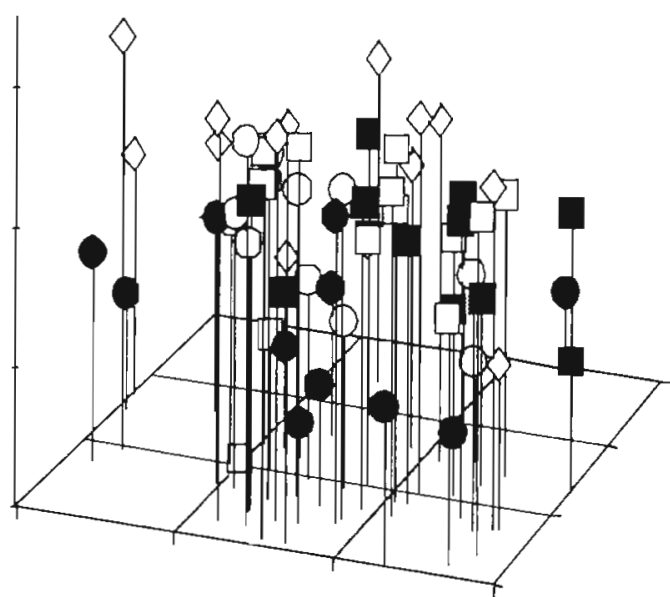

Fig. 3. MDS ordination of core data from the Hahei experimental site. The ordination recorded a stress level of 0.121 $(\diamond)$ Preliminary samples; $(0,0)$ Time 1 ; $(\square, \square)$ Time 2. Solid symbols: samples from the dredged plot; open symbols: samples from the reference plot

less clear cut in Opito Bay than at the Hahei site. Only Ostracods and the bivalves Felaniella zelandica and Nucula nitidula showed consistently lower densities in the dredged plot on both sampling occasions; the polychaete Polydora sp. was significantly less abundant in the dredged plot only on the first sampling occasion (Fig. 4). Some taxa, however (i.e. the crustacean Gynodiastylis laevis, the polychaetes, Goniadides sp. and Macroclymenella stewartensis, and the bivalve Caryocorbula zelandica), showed a marked increase in density in the dredged plot by the second sampling occasion (Fig. 4). This pattern may result from either preferential settlement into the dredged plot (possibly by Caryocorbula zelandica and Macroclymenella stewartensis) or colonization by scavenger/predators (e.g. Goniadides sp.). As at Hahei, those common taxa exhibiting low and/or variable densities (i.e. the crustacean Phoxocephalid complex, and the polychaete Prionospio multicristata) did not show significant differences (Table 5)

Both the total number of individuals and the number of taxa recorded significant site effects (Table 5). The MDS ordination of macrobenthic samples from Opito Bay demonstrate differences in assemblage structure both over time and as a result of dredging (Fig. 5). ANOSIM assessment of differences in the ranked similarity matrix demonstrated an overall difference between factors $(p=0.002)$. Not only are samples from the dredged plot significantly different to those from the reference plot $(p<0.05)$, but samples collected at each time from the reference plot are significantly different from each other $(p<0.05)$ consistant with the strong temporal changes apparent from the univariate analysis at this site.
Table 5. Significance of 2-way ANOVA on common taxa, total number of individuals and number of taxa from the Opito Bay experimental site core samples. Degrees of freedom are as follows: Plot $1_{i}$ Time 1; Interaction $1_{i}$ Error 44 . Probability values above 0.1 are presented as non-significant (ns)

\begin{tabular}{|c|c|c|c|}
\hline Taxa & Plot & Time & Interaction \\
\hline \multicolumn{4}{|l|}{ Crustaceans } \\
\hline Gammaridae & ns & 0.0022 & ns \\
\hline $\begin{array}{l}\text { Gynodiastylis } \\
\text { laevis. }\end{array}$ & ns & ns & 0.0182 \\
\hline Ostracods & 0.001 & 0.001 & 0.0211 \\
\hline $\begin{array}{l}\text { Phoxocephalid } \\
\text { complex }\end{array}$ & ns & ns & ns \\
\hline \multicolumn{4}{|l|}{ Molluscs } \\
\hline $\begin{array}{l}\text { Caryocorbula } \\
\text { zelandica }\end{array}$ & 0.0743 & ns & ns \\
\hline Felaniella zelandica & 0.0037 & 0.0420 & ns \\
\hline Nucula nitidula & 0.0001 & ns & ns \\
\hline \multicolumn{4}{|l|}{ Polychaetes } \\
\hline Euchone sp. & ns & 0.0704 & ns \\
\hline Goniadides sp. & ns & ns & 0.0417 \\
\hline $\begin{array}{c}\text { Macroclymenella } \\
\text { stewartensis }\end{array}$ & 0.0437 & 0.0162 & 0.0104 \\
\hline Polydora sp. & ns & ns & 0.0652 \\
\hline $\begin{array}{l}\text { Prionospio } \\
\text { multicristata }\end{array}$ & ns & ns & ns \\
\hline Nemerteans & $\mathrm{ns}$ & ns & 0.0023 \\
\hline Total no. of individuals & 0.0566 & ns & 0.0873 \\
\hline Total no. of taxa & 0.0040 & 0.0407 & ns \\
\hline
\end{tabular}

\section{DISCUSSION}

This experiment has demonstrated that macrobenthic community structure in dredged areas differed from undredged areas for at least 3 mo at each study site. At both sites significant differences in community structure and in the densities of common macrofaunal taxa were apparent immediately after dredging At both sites over $50 \%$ of the common taxa showed significant plot effects and/or plot $\times$ time interaction effects. The initial responses were all negative, with lower densities in the dredged plot than in the adjacent reference plot. The responses noted 3 mo later were more complex, with differences between the 2 sites. Effects were more pronounced and more often negative at the site that was not commercially exploited (Hahei). Multivariate analysis of community composition also demonstrated differences in assemblage composition between dredged and reference plots at both sites over the course of the study. Differences in the recovery processes at the 2 sites are likely to relate to differences in the initial community composition and to differing environmental characteristics 

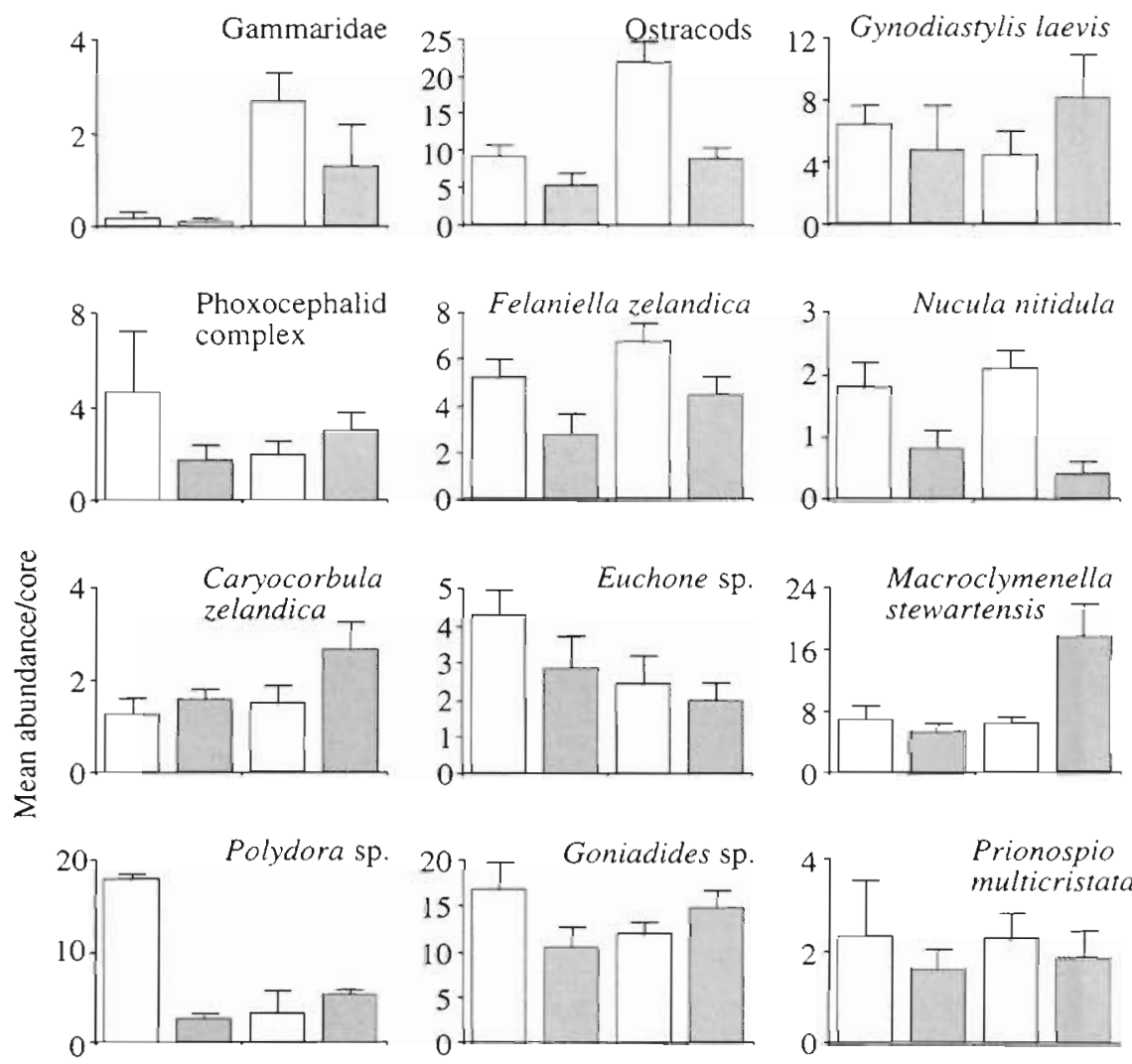

Fig. 4. Mean density ( $\pm \mathrm{SE}$ ) of common taxa, total number of individuals, number of taxa collected in core samples from dredged (shaded) and reference (unshaded) plots at Opito Bay
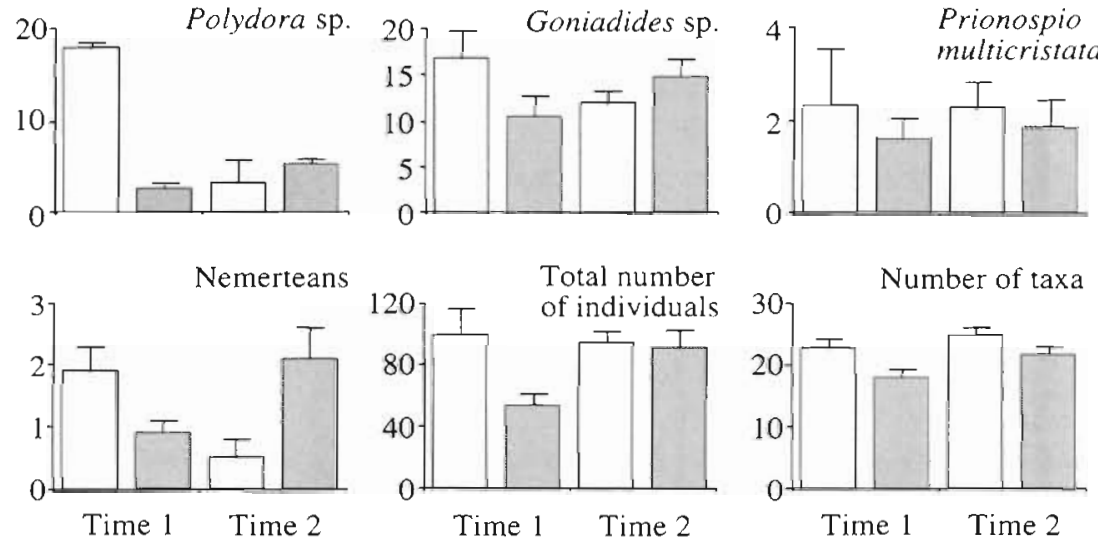

As only 1 dredged and 1 reference plot were studied at each site, it is possible that the observed responses were purely location effects (see Underwood 1989 for further discussion of this problem). However, if this was the case we would expect the analysis of preliminary data collected from each site prior to experimental dredging to have suggested significant differences in the density of common taxa between the 2 plots. This was not so and in view of the size (about $700 \mathrm{~m}^{2}$ each), proximity and similar physical characteristics of the plots, as well as the types of observed response of the macrofauna, we consider such a location effect to be unlikely.

Our experimental assessment of the short-term effects of scallop dredging on macrobenthic communities was quite conservative. Commercial fishers work over much larger areas and repeatedly dredge the same region of the seabed on any one fishing trip,

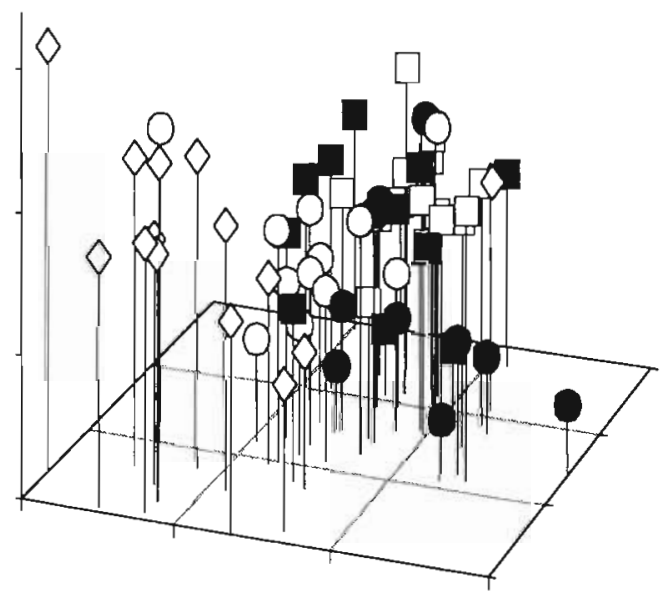

Fig. 5. MDS ordination of core data from the Opito Bay experimental site. The ordination recorded a stress level of 0.138 . $(\diamond)$ Preliminary samples; $(\bigcirc, 0)$ Time $1 ;(\square, \square)$ Time 2. Solid symbols: samples from the dredged plot; open symbols: samples from the reference plot 
hence resulting in a far higher level of bottom disturbance than that used in our experiment. Furthermore, the macrobenthic communities resident at the experimental sites were composed almost entirely of small, short lived species. Effects on these animals are likely through modifications to their habitat, exposure to predators, and resuspension and subsequent transport in the water column. Only a small proportion are expected to be directly crushed and none removed as by-catch. In many other habitats, extensive and repeated fishing disturbance will remove large and long-lived surface and near surface dwelling sedentary organisms (Sainsbury 1988, Rice et al. 1989, Bergman \& Hup 1992, Eleftheriou \& Robertson 1992 Dayton et al. in press.) and select for species with a facultative response to disturbance, with communities becoming dominated by juvenile stages, mobile and rapid colonist species. In our 2 study sites the communities were already dominated by small and short-lived species, due to either natural environmental conditions or fishing pressure, and are therefore less likely to show effects than other community types. Larger organisms, particularly starfish, which could not be quantitatively sampled in our experiment, were collected in the by-catch. That the effects on small sediment dwelling animals lasted 3 mo reflects the strength of the benthic community response to this kind of disturbance.

Other experiments on benthic communities have also demonstrated negative effects of habitat disturbance by fishing (Meyer et al. 1981, Peterson et al. 1987, Bergman \& Hup 1992, Eleftheriou \& Robertson 1992). Modifications to sediment texture and microbial activity (e.g. Churchill 1989, Mayer et al. 1991), or the resuspension of contaminants and increases in ben. thic/pelagic nutrient fluxes (e.g. Krost 1990) have also been demonstrated. However, fishing effects on macrofaunal communities are not always apparent Brylinsky et al. (1994) found no significant effects on intertidal macrofauna after flounder trawling, even though physical conditions were visibly impacted for 2 to 7 mo. The lack of significant effects was attributed to the predominance of subsurface feeding polychaetes and the naturally high levels of storm and ice disturbance in the habitat. In addition the power to detect significant effects was not considered by Brylinsky et al. (1994).

While many studies have revealed influences on the structure and function of benthic systems, it is often difficult to assess the generality of their findings and their long-term and large-scale significance. Correlative surveys, feasible over larger spatial and temporal scales, have been used to infer broader changes in the density of long-lived species or the structure of benthic communities (Sainsbury 1988. Hutchings 1990,
Langton \& Robinson 1990, Witbaard \& Klein 1994), but often can not confidently attribute this change to bottom disturbance by fishing activity. The disparity between effects that can be demonstrated by small-scale field experiments and potential larger scale effects is a problem needing to be carefully and explicitly addressed. For example, the removal of large surface dwelling organisms, as well as the homogenisation of sediment characteristics, will reduce the spatial heterogeneity in benthic communities. Heterogeneity is an important component of the function of ecological systems (Kolasa \& Pickett 1991, Giller et al. 1994, Legendre 1994), and reductions in heterogeneity over large spatial and temporal scales has implications for the maintenance of diversity and stability at the population, community and ecosystem level (e.g. De Angelis \& Waterhouse 1987, Pimm 1991). Theoretical and field based ecological studies of features such as heterogeneity, and processes such as disturbance/recovery can be used to make predictions of potential environmental effects and impacts on the sustainability of fisheries. Such predictions need to take into account the effect of local biotic interactions (e.g. indirect effects on community structure that can occur in response to predator removal; Sih et al. 1985, Kneib 1991) and larger-scale environmental features (e.g. variations in the frequency and intensity of storm disturbance of the seabed; Hall et al. 1990, Brylinsky et al. 1994, Hall 1994) which are likely to influence the identification of any fishing effects. Apart from the influence of physical and biological environmental features, the intensity, frequency and gear used in a particular fishery also needs to be considered in developing hypotheses about potential fishing impacts.

There are a number of approaches that could be taken to provide much needed information on the large-scale changes to natural systems and the sustainable exploitation of resources. Recognition of the possible risks to the environment and the sustainability of resources, through the use of the precautionary principle (Bodansky 1991, Ludwig et al. 1993), by environmental or fisheries managers can, to some extent, overcome the problem of identifying cause and effect relationships over large scales. However, information identifying the degree to which fishing alters marine ecosystems over large spatial and temporal scales will still be useful in providing advice on sustainable exploitation of resources to managers. Adaptive management strategies (Walters \& Holling 1990) could be used as the basis of large experiments, to test predictions of ecological effects and gain much needed information on large-scale effects (Hilborn \& Walters 1981). Marine protected areas (Agardy 1994) may provide suitable controls against 
which to assess fishing impacts. But, as well as the need for adequate control and replication, these approaches also require a commitment to the sustained collection of appropriate data to identify ecological changes, as currently little information is available to specify appropriate time scales over which to assess change. The most straightforward and readily applicable approach is to conduct surveys over appropriately large scales to test a priori predictions gained from theoretical and small-scale field studies. A variety of design and analytical techniques exist that not only enable differences in abundance to be identified from survey data but also indicate why such differences exist (Eberhardt \& Thomas 1991, Legendre 1994).

The experiment presented here described shortterm changes in macrobenthic community structure, associated with bottom disturbance from commercial fishing. As pronounced changes can be identified for a 3 mo period after a single disturbance event in a small area dominated by small and short-lived species, there is the potential for much longer lasting changes to ecosystem structure and function as a result of commercial fishing practices. However, assessing possible large-scale changes is difficult and predicting their effect on ecosystem function and sustainability of fish resources is even more problematic. If studies such as this are integrated with large-scale surveys, designed to test appropriately constrained predictions concerning differences in habitat heterogeneity, biodiversity, life history characteristics of resident species, densities of epifauna and effects on harvestable species, this should provide a practical mechanism to assess the large-scale consequences of fishing within marine ecosystems (Eberhardt \& Thomas 1991). This approach should be particularly effective in providing an appropriate balance between confidence in results and the generality of the findings.

Acknowledgements. We thank Rod Budd, Peter Carter, Rex George, Helen Neil, Rick Thorpe, Theo Stephens, Kerry Hogan, Craig Meiklen and John Nageis for their help with the field work and Richard Ford, Helen Neil, Susan Hasler and Delwyn Hudson for their help with sample processing. We also thank Theo Stephens, Martin Cryer, Rick Pridmore and 3 anonymous reviewers for comments on earlier drafts. Fieldwork was funded by DoC (3.12/518), while manuscript preparation was funded by FRST (CO 1429).

\section{LITERATURE CITED}

Agardy MT (1994) Advances in marine conservation: the role of marine protected areas. TREE 9:267-270

Aronson RB (1990) Onshore-offshore patterns of human fishing activity. Palaios 5:88-93

Bergman MJN, Hup M (1992) Direct effects of beam trawling in macrofauna in a sandy sedıment in the southern North Sea. ICES J mar Sci 49:5-11
Bodansky D (1991) Law: scientific uncertainty and the precautionary principle. Environment 33:43-44

Bray JR, Curtis JT (1957) An ordination of the upland forest communities of Southern Wisconsin. Ecol Monogr 27: $325-349$

Brylınsky M, Gibson J, Gordon DC Jr (1994) Impacts of flounder trawls on the intertıdal habitat and community of the Minas Basın, Bay of Fundy. Can J Fish Aquat Scl 51 $650-661$

Churchill JH (1989) The effect of commercial trawling on sediment resuspension and transport over the middle Atlantic Bight Continental Shelf. Cont Shelf Res 9:841-864

Clarke KR (1993) Non-parametric multivariate analyses of changes in community structure. Aust $J$ Ecol 18:117-143

Clarke KR, Green RH (1988) Statistical design and analysis for a 'biological effects' study. Mar Ecol Prog Ser 46: 213-226

Conover WJ, Iman RL (1981) Rank transformations as a bridge between parametric and nonparametric statistics. Am Stat 35:124-133

Dayton PK. Thrush SF, Agardy MT, Hofman RJ (in press) Environmental effects of fishing. Aquat Conserv 5

De Angelis DL, Waterhouse JC (1987) Equilibrium and nonequilibrium concepts in ecological models Ecol Monogr $57: 1-21$

de Groot SJ (1984) The impact of bottom trawling on benthic fauna of the North Sea. Ocean Mgmt 9:177-190

Eberhardt LL, Thomas JM (1991) Designing environmental field studies. Ecol Monogr 61:53-73

Eleftheriou A, Robertson MR (1992) The effects of experimental scallop dredging on the fauna and physical environment of a shallow sandy community. Neth J Sea Res 30 : $289-299$

Fairweather PG (1991) Statistical power and design requirements for environmental monitoring. Aust J mar Freshwat Res 42:555-567

Folk RL (1968) Petrology of sedmentary rocks. Hemphilis, Austin, TX

Giller PS, Hildrew AG, Raffaelli D (1994) Aquatic ecology: scale, pattern and process. Blackwell Scientific, Oxford

Green RH (1979) Sampling design and statistical methods for environmental biologists. John Wiley and Sons, New York

Hall SJ (1994) Physical disturbance and marine benthic communities: life in unconsolidated sediments. Oceanogr Mar Biol Ann Rev 32:179-239

Hall SJ, Basford DJ, Robertson MR (1990) The impacts of hydraulic dredging for razor clams Ensis sp on an infaunal community. Neth J Sea Res 27:119-125

Hilborn R, Walters CJ (1981) Pitfalls of environmental baseline and process studies. Env Impact Ass Rev 2:265-278

Holme NA (1983) Fluctuations in the benthos of the western Channel. Oceanologica Acta, Proc 17 th European Marine Biological Symposium, p 121-124

Hutchings P (1990) Review of the effects of trawling on macrobenthic epifaunal communities. Aust $\mathrm{J}$ mar Freshwat Res 41:111-120

Jones JB (1992) Environmental impact of trawling on the seabed: a review. NZ J mar Freshwat Res 26:59-67

Kolasa J, Pickett STA (1991) Ecological heterogeneity. Springer-Verlag, New York

Kneib RT (1991) Indirect effects in experimental studies of marine soft-sediment communities. Am Zool 31:874-885

Krost P (1990) The impact of otter-trawl fishery on nutrient release from the sediment and macrofauna of Kieler Bucht (Western Baltic). Ber Inst Meeresk 200

Kruskal JB, Wish M (1978) Multidimentional scaling. Sage Publications, Beverley Hills, CA 
Langton RW, Robinson WE (1990) Faunal association on scallop grounds in the western Gulf of Maine. J exp mar Biol Ecol 144:157-171

Legendre P (1994) Spatial autocorrelation: trouble or new paradigm? Ecology 74:1659-1673

Ludwig D, Hilborn R, Walters C (1993) Uncertanty, resource exploitation, and conservation: lessons from history. Science $260(2): 17-36$

Mayer LM, Schick DF, Findlay RH, Rice DL (1991) Effects of commercial dragging on sedimentary organic matter. Mar environ Res 31:249-261

Messieh SN, Rowell TW, Peer DL, Cranford PJ (1991) The effects of trawling, dredging, and ocean dumping on the Eastern Canadian Continental Shelf seabed. Cont Shelf Res 11:1237-1263

Meyer TL, Cooper RA, Pecci KJ (1981) The performance and environmental effects of a hydraulic clam dredge. Mar Fish Rev 43:14-22

McLoughlin RJ, Young PC, Martin RB, Parslow J (1991) The Australian scallop dredge: estimates of catching efficiency and associated indirect fishing mortality. Fish Res $11: 1-24$

Peterman R, M'Gonigle M (1992) Statistical power analysis and the precautionary principle. Mar Pollut Bull 24:231-234

Peterson CH (1993) Improvement of environmental impact analysis by application of principles derived from manipulative ecology: lessons from coastal marine case histories. Aust J Ecol 18:21-52

Peterson CH, Summerson HC, Fegley SR (1987) Ecological consequences of mechanical harvesting of clams. Fish Bull US 85:281-298

Pimm SL (1991) The balance of nature: ecological issues in the conservation of species and communities. University of Chicago Press, Chicago

This article was presented by D. C. Schneider (Senior Editorial Advisor), St. John's, Newfoundland, Canada
Rice MA, Hickox C, Zehra I (1989) Effects of intensive fishing effort on the population structure of Quahogs, Mercenaria mercenaria (Linnaeus 1758), in Narragansett Bay. J Shellfish Res 8:345-354

Riesen W, Reise K (1982) Macrobenthos of the subtidal Wadden Sea: revisited after 55 years. Helgoländer Meeresunters 35:409-423

Sainsbury KJ (1988) The ecological basis of multispecies fisheries and management of a demersal fishery in tropical Australia. In: Gulland JA (ed) Fish population dynamics, 2nd edn. Wiley, Chichester, p 349-382

Sih A, Crowley P, McPeek M, Petranka J, Strohmeier K (1985) Predation, competition, and prey communities: a review of field experiments. A Rev Ecol Syst 16:269-311

Stewart-Oaten A, Murdoch WM, Parker KR (1986) Environmental impact assessment: pseudoreplication in time? Ecology 67:929-940

Underwood AJ (1989) The analysis of stress in natural populations. Biol J Linn Soc 37:51-78

Underwood AJ (1992) Beyond BACI: The detection of environmental impact on populations in the real, but variable, world. J exp mar Biol Ecol 161:145-178

Walters CJ, Holling CS (1990) Large-scale management experiments and learning by doing. Ecology 71:2060-2068

Warwick RM (1993) Environmental impact studies on marine communities: pragmatical considerations. Aust J Ecol 18: $63-80$

Whitman JD, Sebens KP (1992) Regional variation in fish predation intensity: a historical perspective in the Gulf of Maine. Oecologia 90:305-315

Witbaard R, Klein R (1994) Long-term trends on the effects of the southern North Sea beam trawl fishery on the bivalve mollusc Arctica islandica L. (Mollusca, bivalvia). ICES $\mathrm{J}$ mar Sci 51:99-105

Manuscript first received: March 2, 1995

Revised version accepted: June 20,1995 